\title{
Testing the Effect of the Microbial Consortium on Growth of Vegetable Seedlings in a Farmer's Nursery
}

\author{
C. Jayashree and K.S. Jagadeesh ${ }^{*}$ \\ Department of Agricultural Microbiology, University of Agricultural Sciences, \\ Dharwad-580 005, India \\ *Corresponding author
}

\section{A B S T R A C T}

Keywords

Microbial

Consortium,

Vegetable

Seedlings.

Article Info

Accepted:

24 January 2017

Available Online:

10 February 2017
A microbial consortium consisting of Azospirillum, phosphate solubilizing bacterium (Pseudomonas striata), potassium solubilizing bacterium, PGPR (plant growth promoting rhizobacterium) strain (Pseudomonas sp. B15) and lactic acid bacterium (Leuconostoc mesenteroides) with antifungal activities was prepared. It effect on the growth and biomass of different vegetable seedlings raised in nursery protrays was evaluated in a commercial farmer's nursery. The microbial inoculation resulted in improved plant height and biomass. The per cent increase in plant height and girth of tomato was 57.48 and. 47.61 per cent respectively. While in case of brinjal, it was 42.10 and. 53.60 per cent respectively. And, in chilli, it came to 76.50 and 28.05 per cent increase respectively. Thus from this study, it can be concluded that the microbial consortium consisting of strains with multiple functions can be used to treat cocopeat @ $5 \mathrm{~g} \mathrm{~kg}^{-1}$ to produce quality vegetable seedlings raised in protrays.

\section{Introduction}

Vegetables are the best and the cheapest source of vitamins and minerals. They are an important part of healthy eating and provide a source of many nutrients including potassium, fibre, folate (folic acid), vitamin-A, vitamin-E and vitamin-C. They provide palatability, increase appetite and support fibre for digestion and prevent constipation. Nursery is a place where seedlings are grown, nurtured and handled to make them ready for planting in the main field. Some vegetables with very small sized seeds require special care during their early growth period. These are first sown in the nursery for better care against pathogenic infections, pests and weeds and then transplanted in the main field about four weeks after sowing. Crops grown by raising nursery will yield quite early and fetch higher price in the market, hence are economically profitable. In nurseries, seedlings are generally produced in protrays. These seedlings are easily removed from the protrays for transplanting and the damage to transplants from cell trays is minimal when 
planted in the field, when compared to the use of other types of transplants. Soil less mixtures such as saw dust, cocopeat, perlite, compost etc, are usually used for commercial seedling production. There is a great need to produce quality and healthy seedlings, which are capable of withstanding adverse abiotic and biotic stresses after transplanting with improved mineral nutrient uptake (Nzanza et al., 2011).

A pre-sowing inoculation of planting material as well as the planting medium with the consortia of beneficial microorganisms is an innovative approach for production of quality and healthy seedlings in horticultural production. A microbial consortium is a carrier based product containing nitrogen fixing, phosphorus and potassium solubilising and plant growth promoting microorganisms in a single formulation. The synergistic effect of the formulated microbes can help in providing healthy and vigorous seedlings and considerably reducing the cost of cultivation by reducing fertilizer requirement of vegetables.

The Department of Agricultural Microbiology, College of Agriculture, University of Agricultural Sciences, Dharwad has a collection of efficient Azospirillum, phosphate solubilizing bacterium (Pseudomonas striata), potassium solubilizing bacterium, PGPR (plant growth promoting rhizobacterium) strain (Pseudomonas sp. B15) and lactic acid bacterium (Leuconostoc mesenteroides) with antifungal activities. Application of a mixture of all these strains (as consortium) is likely to enhance plant growth and productivity besides crop protection, due to additive synergistic effect. The use of efficient microbial cultures in the production of nursery seedlings is practically feasible, as the cultures can be mixed with the potting medium (cocopeat) and also can be easily sprayed as it is a small area. Since the seedlings are pre-colonized with the efficient microbes, they are likely to survive better and put forth good growth and yields. Hence, in this context, a microbial consortium was developed, after compatibility testing, and tested in different vegetable crops in the University nurseries in trays and the dosage of $5 \mathrm{~g} \mathrm{Kg}^{-1}$ cocopeat was found optimum (Jayashree et al., 2016).

In this study, this microbial consortium was further validated in protrays in a farmer's commercial nursery. It was evaluated at $\mathrm{M} / \mathrm{s}$. Sinchana Nursery, belonging to Sri. Y. K. Regi at Narendra village, near Dharwad. The crops tested included tomato, brinjal and chilli. Cocopeat was inoculated with the microbial consortium @ $5 \mathrm{~g} \mathrm{~kg}^{-1}$ cocopeat. Uninoculated cocopeat served as control. Seeds of these vegetables were sown in protrays and maintained till 40 days. Plant height and girth of seedlings were measured. All the observations were taken in the selected ten plants. Plant height was measured from the base of the plant up to the tip of the fully opened top leaf. The stem girth was measured using a thread and a scale, averaged and expressed in mm plant ${ }^{-1}$.

It can be observed from Table 1 that the seedlings grown in microbial consortium treated cocopeat performed better than the unioculated control (Plate 1). At 40 days after sowing (DAS), in tomato, microbial consortium treated seedlings showed a height of $32.22 \mathrm{~cm} \mathrm{plant}^{-1}$ and a stem girth of 4.65 $\mathrm{mm}$ plant $^{-1}$, whereas unioculated seedlings showed $20.46 \mathrm{~cm} \mathrm{plant}^{-1}$ height and a stem girth of $3.15 \mathrm{~mm}$ plant $^{-1}$. The per cent increase in plant height and girth comes to 57.48 and. 47.61 per cent respectively. Similarly, in brinjal also, the microbial consortium treated seedlings showed $21.6 \mathrm{~cm}_{\text {plant }}{ }^{-1}$ height and a stem girth of $3.84 \mathrm{~mm}$ plant $^{-1}$, whereas uninoculated seedlings showed $15.20 \mathrm{~cm}$ 
plant $^{-1}$ and a stem girth of $2.50 \mathrm{~mm} \mathrm{plant}^{-1}$. The per cent increase in plant height and girth comes to 42.10 and. 53.60 per cent respectively. In chilli, the microbial consortium treated seedlings showed 24.57 $\mathrm{cm}_{\text {plant }}{ }^{-1}$ and a stem girth of $2.83 \mathrm{~mm} \mathrm{plant}^{-1}$, whereas uninoculated seedlings showed 13.92 $\mathrm{cm}_{\text {plant }}{ }^{-1}$ and a stem girth of $2.51 \mathrm{~mm}_{\text {plant }}{ }^{-1}$. The per cent increase in plant height and girth comes to 76.50 and. 28.05 per cent respectively. Higher girth of seedlings is an advantage as they are known to resist transport shock.

Table.1 Influence of microbial consortium on growth of different vegetable seedlings in a farmer's nursery (40 DAS)

\begin{tabular}{|c|l|c|c|c|c|}
\hline \multicolumn{2}{|c|}{ Treatments } & $\begin{array}{c}\text { plant height }(\mathbf{c m} \\
\left.\text { plant }^{-1}\right)\end{array}$ & $\begin{array}{c}\text { stem girth }(\mathbf{m m} \\
\left.\text { plant }^{-1}\right)\end{array}$ & \multicolumn{2}{c|}{ Percentage increase over control } \\
\cline { 4 - 6 } Tomato & 20.46 & 3.15 & plant height & stem girth \\
\hline \multirow{3}{*}{ Brinjal } & $\begin{array}{l}\text { UIC } \\
\text { Microbial } \\
\text { consortium } \\
\text { treated }\end{array}$ & 32.22 & 4.65 & 57.48 & 47.61 \\
\hline \multirow{3}{*}{ Chilli } & $\begin{array}{l}\text { UIC } \\
\text { Microbial } \\
\text { consortium } \\
\text { treated }\end{array}$ & 15.2 & 2.5 & - & - \\
\hline & $\begin{array}{l}\text { UIC } \\
\text { Microbial } \\
\text { consortium } \\
\text { treated }\end{array}$ & 21.6 & 3.84 & 42.10 & 53.6 \\
\hline
\end{tabular}

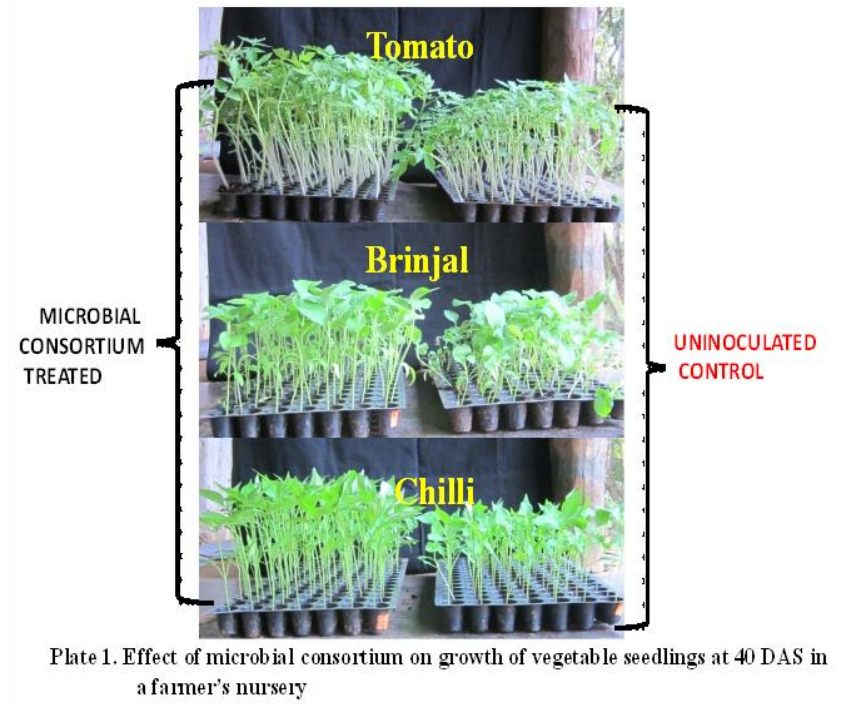

When two or three organisms are inoculated together, they are known to show better performance over single inoculations, possibly due to their synergistic interaction (Belimov et al., 1995; Alagawadi and Gaur, 1988). Besides, the inoculation of mixed cultures of microorganisms with different functional properties is known to enrich the microbial diversity in the rhizosphere of crop plants and thereby enhance microbial interactions. 
In this study, higher plant growth and stem girth may be due to production of plant growth promoting substances (which are known to cause enhanced cell division and root development) by Pseudomonas sp., B15, higher nitrogen fixation by Azospirillum ACD 15, phosphorous and potassium solubilization by phosphorous solubilizing bacterium and potassium solubilizing bacterium respectively, coupled with all nutrients uptake by VAM fungus.

Similarly, Sarvanan et al., (2012) conducted a six months experiment to assess the effect of the consortium on growth of Casuarina equisetifolia seedlings, grown in decomposed coir pith as substrate in root trainers. They observed the highest biomass in the combination of all the three (Frankia + Azospirullum + Phosphobacterium) bio inoculants compared to the control.

It has been suggested that development of plant growth promoting consortium (PGPC), could be a feasible strategy for increased activity and better viability of plant growth promoting rhizobacteria (PGPR). When these strains are made into a microbial consortium, each of the constituent strains of the consortium not only out-competed with others for rhizospheric establishments, but complemented functionally for plant growth promotion (Shenoy and Kalagudi, 2002).

From this study, it can be concluded that the microbial consortium consisting of strains with multiple functions can be used to treat cocopeat @ $5 \mathrm{~g} \mathrm{~kg}^{-1}$ to produce quality vegetable seedlings raised in protrays.

\section{References}

Alagawadi, A.R. and Gaur, A.C. 1998. Associative effect of Rhizobium and phosphate solubilizing bacteria on the yield and nutrient uptake of chickpea. Plant Soil, 105: 241-246.

Belimov, A.A., Kojemiakov, P.A. and Chuvarliyeva, C.V. 1995. Interaction between barley and mixed cultures of nitrogen fixing and phosphate solubilizing bacteria. Plant Soil, 17: 29-37.

Jayashree, C. and Jagadeesh, K.S. 2016, Nursery inoculation of the selected vegetable seedlings with a microbial consortium and its field performance in brinjal (Solanum melongena L.). M.Sc Thesis, Univ. Agric. Sci., Dharwad.

Nzanza, B., Diana, M. and Puffy, S. 2011. Tomato (Solanum lycopersicum L.) seedling growth and development as influenced by Trichoderma harzianum and arbuscular mycorrhizal fungi. African J. Microbiol. Res., 5(4): 425-431.

Sarvanan, T.S., Rajendran, K. and Santhaguru, K. 2012. Selection of suitable biofertilizer for production of quality seedling of Casurina equisetifolia using decomposed coir pith compost in Root Trainers. Asian J. Exptl. Biol. Sci., 3(4): $752-761$.

Shenoy, V.V. and Kalagudi, G.M. 2002. Plant host mediated enhancement of phosphorus use efficiency. In: Nation. Symp. on Mineral Phosphate solubilization- 2002 (A. R. Alagawadi et al., eds.), Univ. Agric. Sci., Dharward, pp. 11-12.

\section{How to cite this article:}

Jayashree M.C., and Jagadeesh, K.S. 2017. Testing the Effect of the Microbial Consortium on Growth of Vegetable Seedlings in a Farmer's Nursery. Int.J.Curr.Microbiol.App.Sci. 6(2): 1636-1639. doi: http://dx.doi.org/10.20546/ijcmas.2017.602.182 